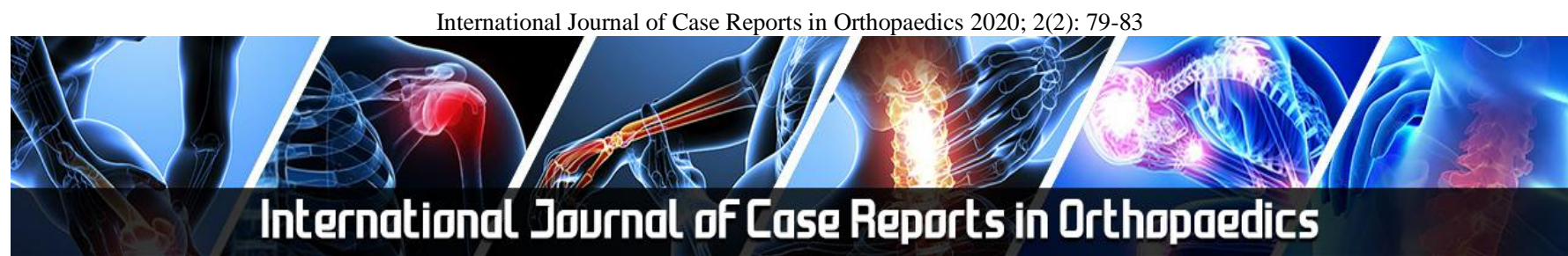

E-ISSN: 2707-8353

P-ISSN: 2707-8345

IJCRO 2020; 2(2): 79-83

Received: 18-05-2020

Accepted: 21-06-2020

Joshi Prateek C

MBBS Assistant Professor

Department of Orthopaedics,

B. J. Govt. Medical College \&

Sassoon General Hospitals,

Pune, Maharashtra, India

Chhattani Tushar M MBBS Assistant Professor

Department of Orthopaedics,

B. J. Govt. Medical College \&

Sassoon General Hospitals,

Pune, Maharashtra, India

Shreesha Parthaje

MBBS. Department of

Orthopaedics, B. J. Govt.

Medical College \& Sassoon

General Hospitals, Pune,

Maharashtra, India

Rishi Raj

MBBS. Resident Doctor,

Department of Orthopaedics,

B. J. Govt. Medical College \&

Sassoon General Hospitals,

Pune, Maharashtra, India
Corresponding Author:

Joshi Prateek C

MBBS Assistant Professor

Department of Orthopaedics,

B. J. Govt. Medical College \&

Sassoon General Hospitals,

Pune, Maharashtra, India

\section{Amputation of an unsalvageable post-traumatic limb in a young Haemophiliac: A multi-faceted clinical dilemma}

\author{
Joshi Prateek C, Chhattani Tushar M, Shreesha Parthaje and Rishi Raj
}

DOI: https://doi.org/10.22271/27078345.2020.v2.i2b.33

Abstract

A twenty-nine-year-old male presented to the emergency ward of our institute with a history of having been involved in a road traffic accident with a heavy motor vehicle (HMV), 18 hours ago, with trauma to his left lower limb.

Arteriovenous Doppler evaluation of the affected limb confirmed devascularization, and radiographs showed fracture of the femur in supracondylar region and tibial diaphysis with significant soft tissue injury (Letts and Vincent type D floating knee).

Due to the prolonged ischemia time of 18 hours, the Mangled Extremity Severity Score (MESS) of 10, and the contaminated nature of the wound, it was decided to proceed with Guillotine above-knee amputation.

However, a detailed history-taking revealed the patient to be a sufferer of Hemophilia Type A (Coagulation factor VIII deficiency). The patient was stabilized hemodynamically, and supplemented with Factor VIII following which the amputation was done successfully. This case report documents his perioperative and postoperative course in the hospital, ending with his discharge with a small wound healing by secondary intention.

Surgical procedures in hemophiliacs have always presented as clinical dilemmas, with increased blood loss, poor tissue perfusion, and infective events adding to the postoperative complications.

Lower limb amputations in sufferers of hemophilia are very rare, with less that fifty cases being found in the global medical literature. A meta-analysis of said cases reveals the vast majority to have been due to infective indications or for management of hemophilic pseudo-tumours, and post-traumatic above knee amputations are virtually unheard of in such a clinical scenario.

The presence of a traumatic vascular insult in this case, provided a rare clinical predicament, and the successful management of this Catch-22 situation makes for a unique situation.

Keywords: Amputation, hemophilia, fracture, trauma, vascular injury, Factor VIII

\section{Introduction}

Haemophilia A, also called classical hemophilia, is a condition resulting from the congenital deficiency of coagulation factor VIII, which results in excessive haemorrhage, either spontaneous or in a post-traumatic setting. With an incidence of 1 in 5000 males and spanning $80 \%$ of hemophilia cases, it is the most common of all inherited disorders of coagulation ${ }^{[1]}$.

It can be graded into three clinical types based on the severity of presentation, as below ${ }^{[2]}$.

Table 1: Show the Grade Factor Percentage of Normal

\begin{tabular}{|c|c|c|c|}
\hline SR. & Grade & Factor Level (Iu/MI) & Factor Percentage of Normal \\
\hline 1. & Mild & $<0.01$ & $<1 \%$ \\
\hline 2. & Moderate & $0.01-0.04$ & $1-4 \%$ \\
\hline 3. & Severe & $0.05-0.40$ & $5-40 \%$ \\
\hline
\end{tabular}

Severe cases tend to present with episodes of spontaneous haemorrhage, whereas mild to moderate variants bleed excessively in a traumatic setting.

Compound fractures are a common occurrence in recent times with an incidence of 30.7 per 100000 population per year. High-energy road traffic accidents form a large part of the demography of these patients with a proportion of $34.1 \%$. Young males are frequently affected ${ }^{[3]}$. 
The constellation of compound polytrauma in a patient presents a unique clinical dilemma in terms of management as well as prognostication.

\section{Case Details}

A young male patient aged 29 years, presented to the emergency ward of our institute with a history of a road traffic accident eighteen hours ago. The patient had sustained severe, high-energy trauma to his left thigh and leg and had a $3 \times 5 \mathrm{~cm}$ bleeding wound on the anteromedial aspect of the leg in proximity to the shin of the tibia.

Osseous examination revealed fractures of the left distal femur near the supracondylar region, and diaphyseal fracture of the ipsilateral tibia. The patient showed hemodynamic signs of evolving hemorrhagic shock, with tachycardia (heart rate $140 \mathrm{bpm}$ ), tachypnoea (respiratory rate $22 \mathrm{cpm})$ and hypotension $(80 / 60 \mathrm{mmHg})$. The patient was drowsy but obedient to verbal commands, with a Glasgow Coma Score (GCS) of 13/15.

A complete hemogram demonstrated a hemoglobin of 9.2 against a hematocrit of 24.2, and depressed counts of erythrocytes. Platelet counts were 106,000, and there was leukocytosis with raised erythrocyte sedimentation rate (ESR).

Further history taking revealed the patient to be a sufferer of mild to moderate Haemophilia A, and prior records of Factor VIII supplementation were unavailable.

Radiographs of the limb corroborated the findings, confirming a Letts and Vincent type D floating knee.

Based on the clinic-radiologic profile and with the hematological investigation reports, the patient was managed as a case of polytrauma with impending Systemic Inflammatory Response Syndrome (SIRS), and stabilized in the emergency room itself with bilateral broad-gauge intravenous access, Foley's urinary catheter, oxygen and fluid supplementation, and splintage to the fracture after cleaning and dressing of the wounds.

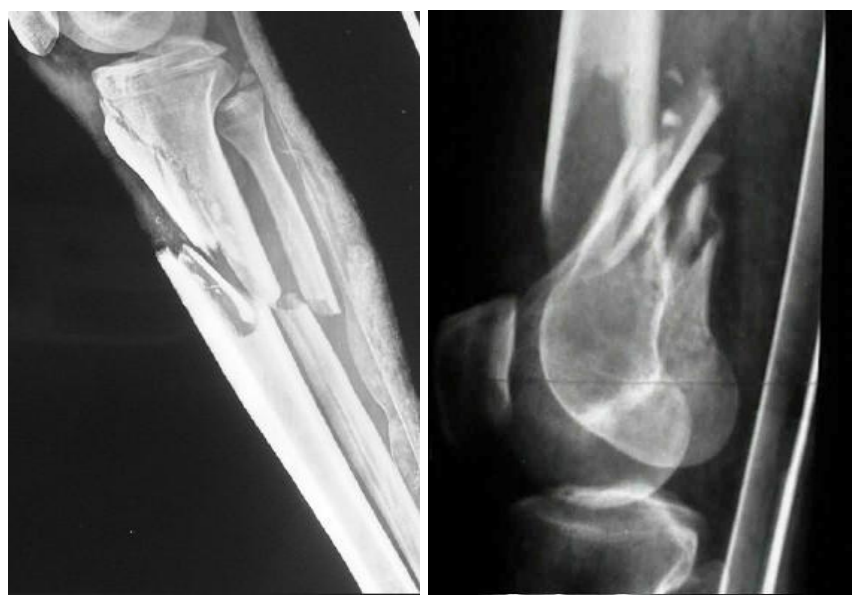

Fig 1: Lateral radiographs of the distal femur and proximal tibia.

On clinical examination, the affected lower limb was found to be cold and insensate from the mid-thigh distally till the toes, with the popliteal artery, anterior and posterior tibial arteries, and dorsalis pedis artery not clinically palpable.

Spontaneous movements were absent from the limb. The patient was subjected to an immediate arteriovenous Doppler examination which demonstrated absent colour flow in the three distal vessels, and minimal monophasic waveform in the proximal popliteal artery.

Based on the trauma time of 18 hours, the Mangled Extremity Severity Score was calculated to be 10 .

\begin{tabular}{|c|c|c|c|}
\hline Type & Characteristics & Lesions & Sutures \\
\hline \multicolumn{4}{|c|}{ Group of skeletal lesions and soft tissue } \\
\hline 1 & Low energy & Sharp wound, simple closed fracture, projectile low-caliber firearm & 1 \\
\hline 2 & Medium energy & Multiple or exposed fractures, dislocation, moderate crush injury & 2 \\
\hline 3 & High energy & Explosion gunshot wound from a high-speed firearm & 3 \\
\hline 4 & Massive crushing & Fall from a tree, train accident, smothering & 4 \\
\hline \multicolumn{4}{|c|}{ Shock group } \\
\hline 1 & $\begin{array}{l}\text { Hemodynamically } \\
\text { normotensive }\end{array}$ & Stable blood pressure & 0 \\
\hline 2 & Transient hypotension & Unstable pressure, but responding to intravenous fluid & 1 \\
\hline 3 & Prolonged hypotension & $\begin{array}{c}\text { Systolic pressure of }<90 \mathrm{mmHg} \text { and responding to intravenous infusion } \\
\text { of fluid only in the operating room }\end{array}$ & 2 \\
\hline \multicolumn{4}{|c|}{ Ischemic group } \\
\hline $1^{*}$ & Absence & Pulse without signs of ischemia & $0^{*}$ \\
\hline 2* & Mild & Pulse reduced without signs of ischemia & $1^{*}$ \\
\hline $3^{*}$ & Moderately & $\begin{array}{l}\begin{array}{l}\text { No pulse on Doppler imaging, prolonged capillary refill, paresthesia, } \\
\text { decreased motor activity }\end{array}\end{array}$ & $2^{*}$ \\
\hline $4^{*}$ & serious & Pulseless, cold limb, which is paralyzed and numb without capillary refill & $3 *$ \\
\hline \multicolumn{4}{|c|}{ ( } \\
\hline 1 & & $<30$ years & 0 \\
\hline 2 & & $30-50$ years & 1 \\
\hline 3 & & $>50$ years & 2 \\
\hline
\end{tabular}

Fig 2: Mangled Extremity Severity Score (MESS) 
In view of the MESS and the non-salvageable nature of the limb, it was decided to take up the patient for a Guillotine above knee amputation, and the decision of primary closure versus proceeding with an open stump, was deferred to the intra-operative phase.

In consultation with internal medicine specialists, the Factor VIII correction was provided preoperatively using the following formula ${ }^{[4,5]}$.

Required dosage in IU $=$ Desired factor level $(\%) \times$ Weight (kg) $\times 0.5$

The patient was given inj. Factor VIII as a 2000 IU bolus 30 minutes prior to the incision, and followed up with an infusion of 1000 IU B.I.D. over the postoperative period.

With the patient hemodynamically stabilized, he was taken up for Guillotine above knee amputation. Intraoperatively, the supracondylar femur fracture being closed at presentation, no contamination of the soft tissue was found, and the decision was taken to primarily close the amputation site.

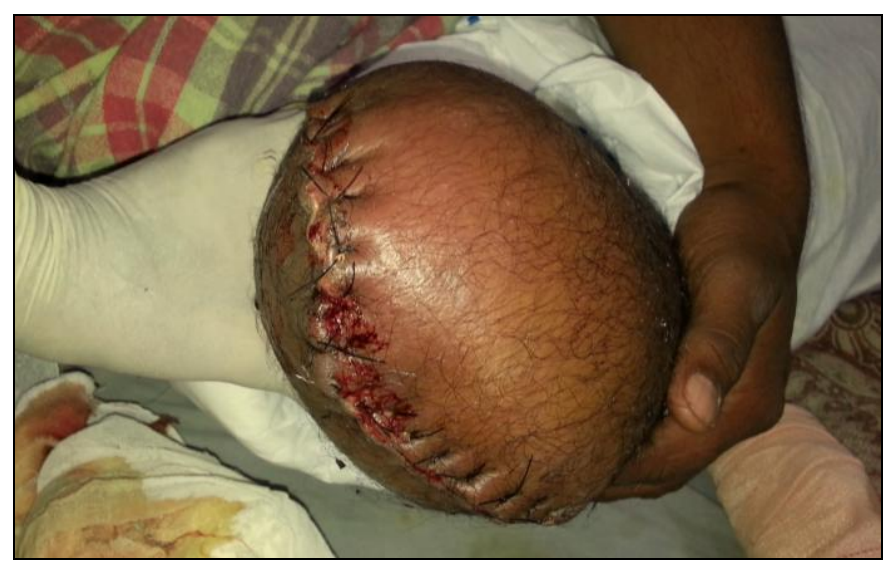

Fig 3: Evidently clean wound, postoperative day 1.

Over the course of the next seven days, the dose of Factor VIII infusion was titrated with reference to serial estimations of activated Partial Thromboplastin Time (aPTT) assay.

The patient was stabilized on a reduced bis-in-die dosage of Factor VIII; however, on the seventh post-operative day the patient developed local inflammatory symptoms and spikes of pyrexia and underwent an open debridement of the stump.

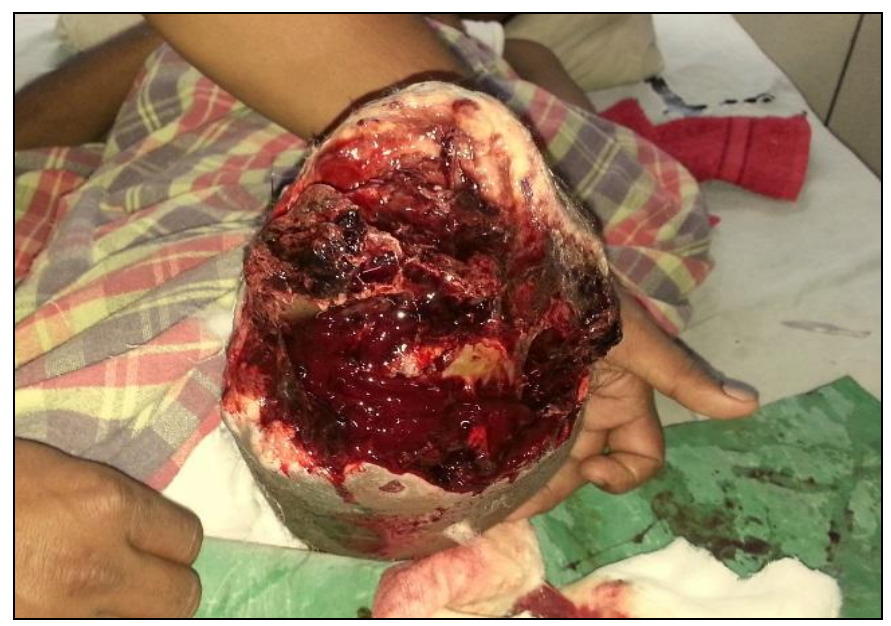

Fig 4: The opened wound, with a large clot in the posteromedial quadrant, presumably the nidus of infection.

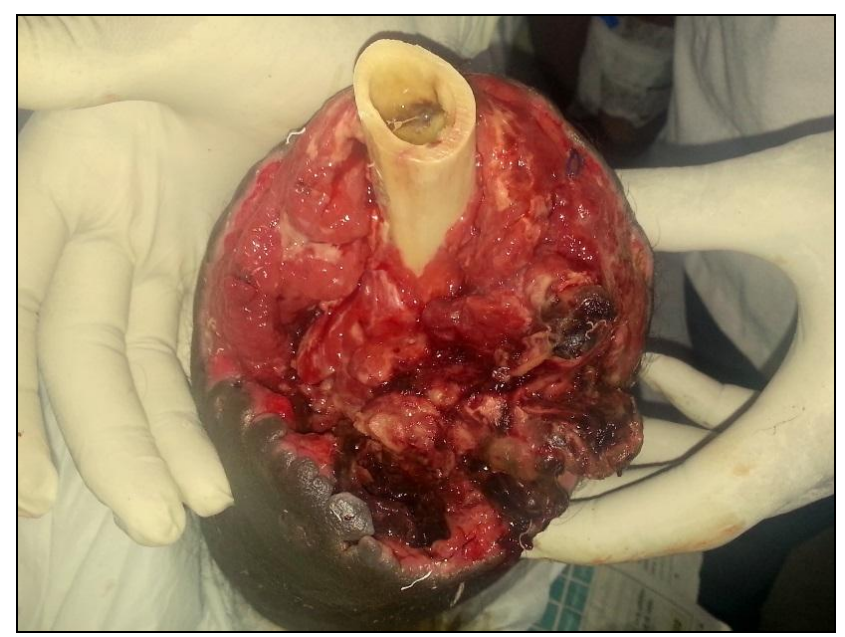

Fig 5: Post debridement status, with the coagulum having been removed en masse. The infected medullary canal was curetted and bone was revised after the photograph.

The patient underwent one more radical debridement and gradual titration of Factor VIII supplementation, along with pus-culture directed choice of antimicrobial agents. With the rapidly contracting wound and healthy granulation tissue, the option of closure was not reconsidered and the wound was allowed to heal by secondary intention.

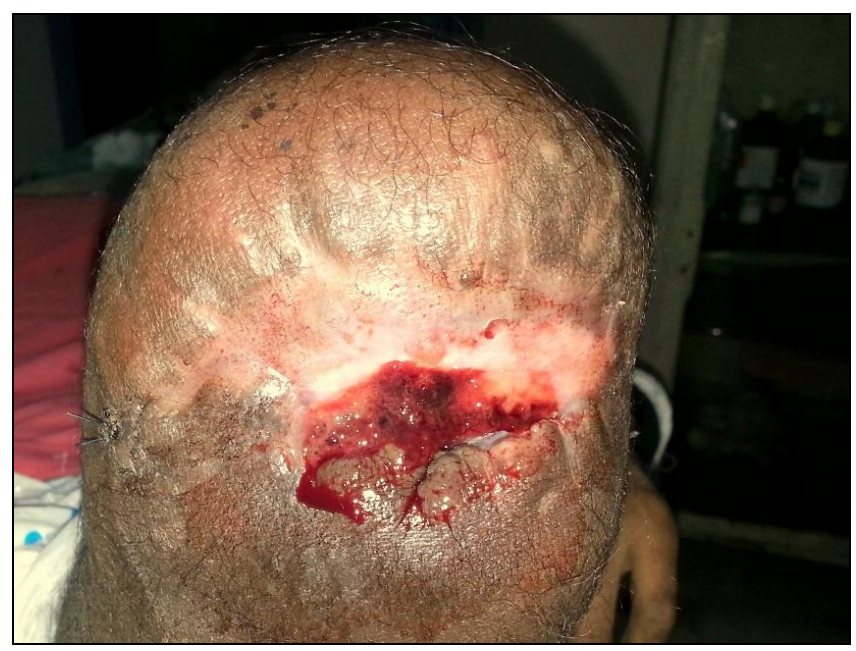

Fig 6: Clean wound with healthy granulation tissue at 8 weeks postoperative.

\section{Discussion and Review of Literature}

Though Hemophilia is one of the very common bleeding disorders in our part of the world, and one of the commonest congenital haemorrhagic diseases known, its coexistence with other conditions can present with unique and challenging clinical scenarios.

The incidence of high-energy road traffic accidents and the frequency of Haemophilia in the general population favours a likelihood of the two coinciding, however, literature related to such scenarios is rare.

Severe trauma to the lower extremity is a common cause of amputation as an end-result, especially when associated with severe soft tissue loss and wound contamination ${ }^{[6]}$

Poor outcomes of amputations and limb reconstructions are gauged by the Sickness Impact Profile, a patient-reported outcome measure of multidimensional nature. Poor socioeconomic strata, low levels of education, poverty, and major complications all reflect on the SIP to bode a less favourable 
outcome, as seen in the patient under discussion ${ }^{[7]}$.

In addition, in a post-traumatic patient with evolving systemic inflammatory response syndrome (SIRS), the values of Factor VIII as obtained on laboratory testing may be subject to variations secondary to elevated and fluctuant levels of epinephrine, fibrinogen, and other acute inflammatory mediators, making clinical correlation a challenge ${ }^{[8]}$.
Among the very first recorded cases of post-traumatic amputations has been cited in 1932, from Nashville, Tennessee, an upper limb amputation for a fractured distal humerus complicated by gas gangrene [9] Similarly, an above-knee amputation in a hemophiliac was reported for a young male with compound diaphyseal tibia fracture, by Schuster et al in $19481^{[10]}$.

A tabulated review of literature in this scenario, is as below.

\begin{tabular}{|c|c|c|c|c|c|c|c|c|}
\hline Author & $\begin{array}{c}\text { Indication } \\
\text { For Amputation }\end{array}$ & $\begin{array}{c}\text { Presence } \\
\text { of Infection } \\
\text { Preoperative }\end{array}$ & $\begin{array}{c}\text { Upen or } \\
\text { Closed } \\
\text { Amputation }\end{array}$ & $\begin{array}{l}\text { Postoperative } \\
\text { Infoction }\end{array}$ & $\begin{array}{c}\text { Bleeding } \\
\text { Postoperative }\end{array}$ & $\begin{array}{c}\text { wound } \\
\text { Healing } \\
\text { Time }\end{array}$ & $\begin{array}{c}\text { Factor } \\
\text { VIII }\end{array}$ & Results \\
\hline $\begin{array}{l}\text { Biggs and } \\
\text { MacFarlane }\end{array}$ & $\begin{array}{l}\text { Infocted pseudo- } \\
\text { tumor left tib- } \\
\text { ial area (knee } \\
\text { disarticulation) }\end{array}$ & Yes & Closed & Yes & Yes & $\begin{array}{l}\text { Time not } \\
\text { specified }\end{array}$ & 0 per cent & Survival \\
\hline $\begin{array}{l}\text { Biggs and } \\
\text { MacFarlane }\end{array}$ & $\begin{array}{l}\text { Infected hema- } \\
\text { toma right calf, } \\
\text { gangrene foot, } \\
\text { BK }\end{array}$ & Yes & Closed & Not specified & Not specified & $3 \mathrm{mos}$. & 0 per cent & Survival \\
\hline $\begin{array}{l}\text { Biggs and } \\
\text { MacFarlane }\end{array}$ & $\begin{array}{l}\text { Pseudotumor. } \\
\text { left thigh, AK } \\
\text { (same patient } \\
\text { as above) }\end{array}$ & Not specified & Closed & Not specified & $\begin{array}{l}\text { Recognized } \\
\text { tenth postop. } \\
\text { day }\end{array}$ & $3 \mathrm{mos}$ & 0 per cent & Survival \\
\hline $\begin{array}{l}\text { Marder and } \\
\text { Shulman }\end{array}$ & $\begin{array}{l}\text { Non-union tibial } \\
\text { fracture, right- } \\
\text { knee disarticu- } \\
\text { lation }\end{array}$ & Not specified & Closed & Yes & $\begin{array}{l}\text { Recognized } \\
\text { seventh day }\end{array}$ & $6 \mathrm{mos}$. & $?$ & Survival \\
\hline $\begin{array}{l}\text { Lewis and } \\
\text { associates }\end{array}$ & $\begin{array}{l}\text { Pseudotumor left } \\
\text { thigh, AK }\end{array}$ & No & Closed & $\begin{array}{l}\text { Recognized } \\
\text { fifth day }\end{array}$ & $\begin{array}{l}\text { Recognized } \\
\text { fourteenth } \\
\text { day }\end{array}$ & 12 mos. & 0 per cent & Survival \\
\hline $\begin{array}{l}\text { Albright and } \\
\text { associates }\end{array}$ & $\begin{array}{l}\text { Osteomyelitis } \\
\text { right femur, hip } \\
\text { disarticulation }\end{array}$ & Yes & Closed & Not specified & Sixtoenth day & 6.5 mos. & $?$ & Survival \\
\hline $\begin{array}{l}\text { Pappas and } \\
\text { associates }\end{array}$ & $\begin{array}{l}\text { Infected hema- } \\
\text { toma right } \\
\text { thigh, osteo- } \\
\text { myelitis right } \\
\text { femur (pseu- } \\
\text { dotumor). hip } \\
\text { disarticulation }\end{array}$ & Yes & Closed & Not specified & $\begin{array}{l}\text { First day and } \\
\text { firth day }\end{array}$ & 3 mos. & $23 \mathrm{per} \operatorname{cen}$ & Survival \\
\hline $\begin{array}{l}\text { Miles, Von } \\
\text { Kaulla, Von } \\
\text { Kaulla }\end{array}$ & $\begin{array}{l}\text { Left AK, osteo- } \\
\text { myelitis left } \\
\text { tibia and fibula }\end{array}$ & $Y \propto s$ & Closed & $\begin{array}{l}\text { Recognized } \\
\text { twenty- } \\
\text { eighth day }\end{array}$ & $\begin{array}{l}\text { Seventh day } \\
\text { small amount } \\
\text { twenty- } \\
\text { eighth day } \\
\text { wound do- } \\
\text { hiscence and } \\
\text { bleeding }\end{array}$ & $3.5 \mathrm{mos}$. & $\begin{array}{l}\text { Not } \\
\text { specified }\end{array}$ & Survival \\
\hline Schuster & $\begin{array}{l}\text { Fracture left fib- } \\
\text { ula, gas gan- } \\
\text { grène, left AK }\end{array}$ & $\begin{array}{l}\text { Yes } \\
\text { (gas gan- } \\
\text { grene sep- } \\
\text { ticemia) }\end{array}$ & Closed & $\begin{array}{l}\text { Second day } \\
\text { (stump and } \\
\text { septicemia) }\end{array}$ & Eighth day & $\begin{array}{l}\text { Incompletely } \\
\text { healed at } \\
8 \text { mos. }\end{array}$ & $\begin{array}{l}\text { Not } \\
\text { specified }\end{array}$ & Survival \\
\hline Egeberg & $\begin{array}{l}\text { Pseudotumor left } \\
\text { thigh, hip dis- } \\
\text { articulation }\end{array}$ & Not specified & Not specified & Not specified & Sixth day & Not specified & $\begin{array}{l}\text { Less than } \\
1 \text { per cent }\end{array}$ & Survival \\
\hline $\begin{array}{l}\text { Abell and } \\
\text { Bailey }\end{array}$ & $\begin{array}{l}\text { Pseudotumor left } \\
\text { thigh, AK }\end{array}$ & Yes & Closed & Immediate & Sixth day & Not healed & $\begin{array}{l}\text { Not } \\
\text { specified }\end{array}$ & $\begin{array}{l}\text { Death } 2 \\
\text { mos. } \\
\text { post-am- }\end{array}$ \\
\hline $\begin{array}{l}\text { Staas and } \\
\text { associates }\end{array}$ & $\begin{array}{l}\text { Infected hemar- } \\
\text { throsis, osteo- }\end{array}$ & Yes & Closed & $\begin{array}{l}10 \text { days } \\
\text { postop. }\end{array}$ & $\begin{array}{l}10 \text { days } \\
\text { postop. }\end{array}$ & $12 \mathrm{mos}$. & 4 per cent & Surviyal \\
\hline
\end{tabular}

As evident from the above, majority amputations in haemophiliacs were for thea indications of either a hemophilic pseudotumour, or for infection. One case of knee disarticulation following distal tibial infected nonunion, has been reported in 1970 by Marder and Shulman et al. ${ }^{[11]}$

Many of the above cases also appear to have been complicated by either postoperative stump sepsis, or septicemia.

Minor surgical procedures such as lipoma excisions, or dental procedures, are routinely reported in the literature and are carried out with good outcomes ${ }^{[12]}$.

\section{Conclusion}

Very few cases of post traumatic lower limb amputation in hemophiliac patients have been reported in the global medical literature. Amputations as an entirety in such cases, though slightly commoner, are most likely secondary to infections or hemophilic pseudotumours.
Majority of post traumatic amputations are seen to have been done within a week of trauma, not many cases of amputation within 24-48 hours have been noted. Secondary intention is also not a commonly deployed mode of healing for such stumps, and outcomes in general, have been unsatisfactory.

This case represents a unique clinical management dilemma, and expedient management with meticulous maintenance of Factor VIII levels, have contributed to the outcome.

\section{References}

1. Salen P, Babiker HM, Hemophilia A. [Updated 2020 Nov 19]. In: StatPearls [Internet]. Treasure Island (FL): Stat Pearls Publishing 2020 Jan-. Available from: https://www.ncbi.nlm.nih.gov/books/NBK470265/

2. World Federation of Hemophilia. WFH guidelines for the management of hemophilia. [Accessed on 05/04/2017]. Available 
at: https://www1.wfh.org/publication/files/pdf-

1472.pdf.

3. Haeberle HS, Navarro SM, Power EJ, Schickendantz MS, Farrow LD, Ramkumar PN. Prevalence and Epidemiology of Injuries Among Elite Cyclists in the Tour de France. Orthop J Sports Med 2018;6(9):2325967118793392

4. The Australian Haemophilia Centre Doctors Organisation Guidelines for the Management of Patients with Haemophilia Undergoing Surgical Procedures. 2005. [Last accessed on 2016 Jul 14]. Available from: http://www.ahcdo.org.au/publications/cid/1/parent/0/t/p ublications/parent-name/Guidelines.

5. Sethi M, Gurha P. Perioperative management of a patient with haemophilia-A for major abdominal surgery. Indian journal of anaesthesia 2017;61(4):354355. https://doi.org/10.4103/ija.IJA_96_17

6. Molina CS, Faulk JB. Lower Extremity Amputation. [Updated 2020 Sep 21]. In: StatPearls [Internet]. Treasure Island (FL): StatPearls Publishing 2020 Jan-. Available from: https://www.ncbi.nlm.nih.gov/books/NBK546594/

7. Bosse MJ, MacKenzie EJ, Kellam JF, Burgess AR, Webb LX, Swiontkowski MF, et al. An analysis of outcomes of reconstruction or amputation after legthreatening injuries. N Engl J Med 2002;347(24):192431.

8. Mansouritorghabeh $\mathrm{H}$. Clinical and laboratory approaches to hemophilia a. Iranian journal of medical sciences 2015;40(3):194-205.

9. Blalock A. Amputation Of Arm Of Patient With Hemophilia. Journal of the American Medical Association 1932;99(21):1777. Doi:10.1001/jama.1932.27410730001011

10. Craddock CG, Fenninger JR, Simmons LD. BRADFORD: Hemophilia, Problem of Surgical Intervention for Accompanying Diseases, Review of the Literature and Report of a Case. Ann. Surg 1948;128:888-903,

11. William E Staas JR, John F Ditunno JR, John J Gartland, Sandor S Shapiro, MD Philadelphia, Pennsylvania

12. Tarnay TJ. Surgery in the Hemophiliac Patient. Archives of Surgery 1966;93(2):271. doi:10.1001/archsurg.1966.013300200630 